\title{
Biodiversity of shallow-water sponges (Porifera) in Singapore and description of a new species of Forcepia (Poecilosclerida: Coelosphaeridae)
}

\author{
Swee-Cheng $\operatorname{Lim}^{1,3}$, Nicole J. de Voogd ${ }^{2}$, Koh-Siang Tan ${ }^{1}$ \\ ${ }^{1}$ Tropical Marine Science Institute, National University of Singapore, 18 Kent Ridge Road, Singapore 119227, \\ Singapore \\ ${ }^{2}$ Netherlands Centre for Biodiversity, Naturalis, PO Box 9517, 2300 RA Leiden, The Netherlands \\ ${ }^{3}$ E-mail:tmslsc@nus.edu.sg
}

Key words: intertidal, Southeast Asia, sponge assemblage, subtidal, tropical

\begin{abstract}
A surprisingly high number of shallow water sponge species (197) were recorded from extensive sampling of natural intertidal and subtidal habitats in Singapore (Southeast Asia) from May 2003 to June 2010. This is in spite of a highly modified coastline that encompasses one of the world's largest container ports as well as extensive oil refining and bunkering industries. A total of 99 intertidal species was recorded in this study. Of these, 53 species were recorded exclusively from the intertidal zone and only 45 species were found on both intertidal and subtidal habitats, suggesting that tropical intertidal and subtidal sponge assemblages are different and distinct. Furthermore, only a third of the fouling species of sponges from a previous study was recorded in this study, thus suggesting that sponge assemblages from natural and fouling communities in the tropics are different as well. A new species, Forcepia (Forcepia) vansoesti is described from Singapore. Members of this genus possess unique spicules shaped in the form of a pair of forceps. The new species is distinguished from its congeners in having the largest forceps (nearly $300 \mu \mathrm{m}$ in length) so far recorded in the Indo-Pacific.
\end{abstract}

\section{Contents}

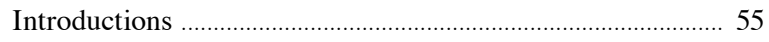

Material and methods ……………………………………........ 56

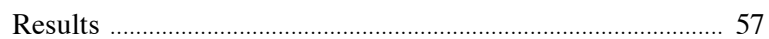

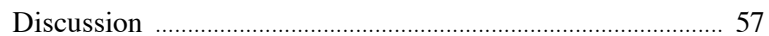

Sponge diversity in Singapore ………………………........ 57

Intertidal sponges ................................................................... 59

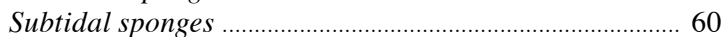

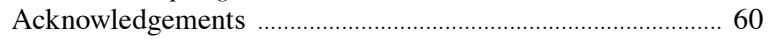

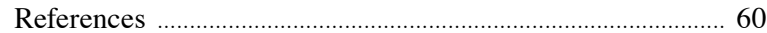

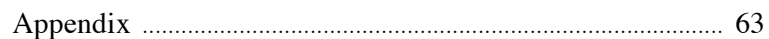

\section{Introduction}

Until very recently, the sponge fauna of Singapore has not been a subject of active research. Cliona (as Spon- gia) patera (Hardwicke, 1822) was the first sponge described from Singapore in the $19^{\text {th }}$ century. This was followed by Leucosolenia flexilis (Haeckel, 1872), Coelocarteria singaporensis (Carter, 1883) (as Phloeodictyon), and Callyspongia (Cladochalina) diffusa Ridley (1884). Subsequently, Dragnewitsch (1906) recorded 24 sponge species from Tanjong Pagar and $\mathrm{Pu}-$ lau Brani in the Singapore Strait. A further six species of sponge were reported from Singapore in the 1900s, although two species, namely Cinachyrella globulosa (as Psetalia) and Pheronema hemisphaericum (as Labaria), were mistaken by Gray (1873) to be collected from Singapore (Lim et al., 2009). Dr A.B. Meyer, the sender of the sponge materials to Gray, clarified that the two sponge species were actually obtained from an area between Cebu and Bohol in the Philippines (see van Soest et al., 2010). Recent additions to the species list include observations from general biodiversity surveys (Chuang, 1961, 1973, 1977; Chou and Wong, 1985) but no voucher specimens were preserved from these studies. The first recent sponge fauna diversity survey, complete with voucher specimens, was done by Hooper et al. (2000). Some 80 species were reported, 15 were identified to species, and about 60 distinct species were identified to genus. This was followed by a study carried out by de Voogd and Cleary (2009), in which they recorded some 80 species (47 identified to species and the rest to genus) from their short survey while examining variation in sponge composition in Singapore coral reefs. In the same year, Lim et al. (2009) recorded 62 species of fouling sponges on navigational buoys. Notably, two new species were reported recently: Tethycometes radicosa Lim and Tan, 2008 dredged from a muddy seabed in the Singapore Strait and Suberites diversicolor Becking and Lim, 2009 from estuarine waters. Lastly, a collection of 76 curated sponge specimens at the collection of the Zoological 
Museum of Amsterdam (ZMA - now NCB Naturalis) collected by H. Moll between January 1977 and December 1978, was partially identified by van Soest (pers. comm.) to comprise some 50 species (unpublished data).

This study aims to provide a comprehensive inventory of shallow water sponge fauna in Singapore based on an eight-year survey of intertidal and subtidal habitats. A new species of Forcepia (Forcepia) (Coelosphaeridae) is also described from the coral reefs of the Singapore Strait.

\section{Material and methods}

Thirty localities comprising 126 stations in Singapore waters (Fig. 1, Tables S1-2) were sampled for sponges between May 2003 to June 2010. Of these, 58 of these stations were intertidal (Table S1) and the remaining 68 stations were subtidal (Table S2). The island of Singapore is located between latitudes $1^{\circ} 09^{\prime} \mathrm{N}$ and $1^{\circ} 29^{\prime} \mathrm{N}$ and longitudes, $103^{\circ} 38^{\prime} \mathrm{E}$ and $104^{\circ} 06^{\prime} \mathrm{E}$ and is bounded by the Johor Strait in the north and the Singapore Strait in the south (Fig. 1). The Singapore Strait is located slightly above $\left(1^{\circ} \mathrm{N}\right)$ of the equator and is about $16 \mathrm{~km}$ wide, separating Singapore and Riau Islands of Indonesia. The Johor Strait to the north of Singapore Island is considerably narrower. There are over 40 islands, most of them located in the Singapore Strait. The habitats surveyed included lagoons, beaches, reef flats, mangroves, estuaries, patch reef, fringing reef, coral reef, reef slope and seabed. Substrata found in these habitats include mud, sand, rock, boulder, coral rubble, shelf grit. Singapore has semi-diurnal tides, with a tidal range is of $3 \mathrm{~m}$. Lowest spring tides occur typically either in the morning or evening, and there

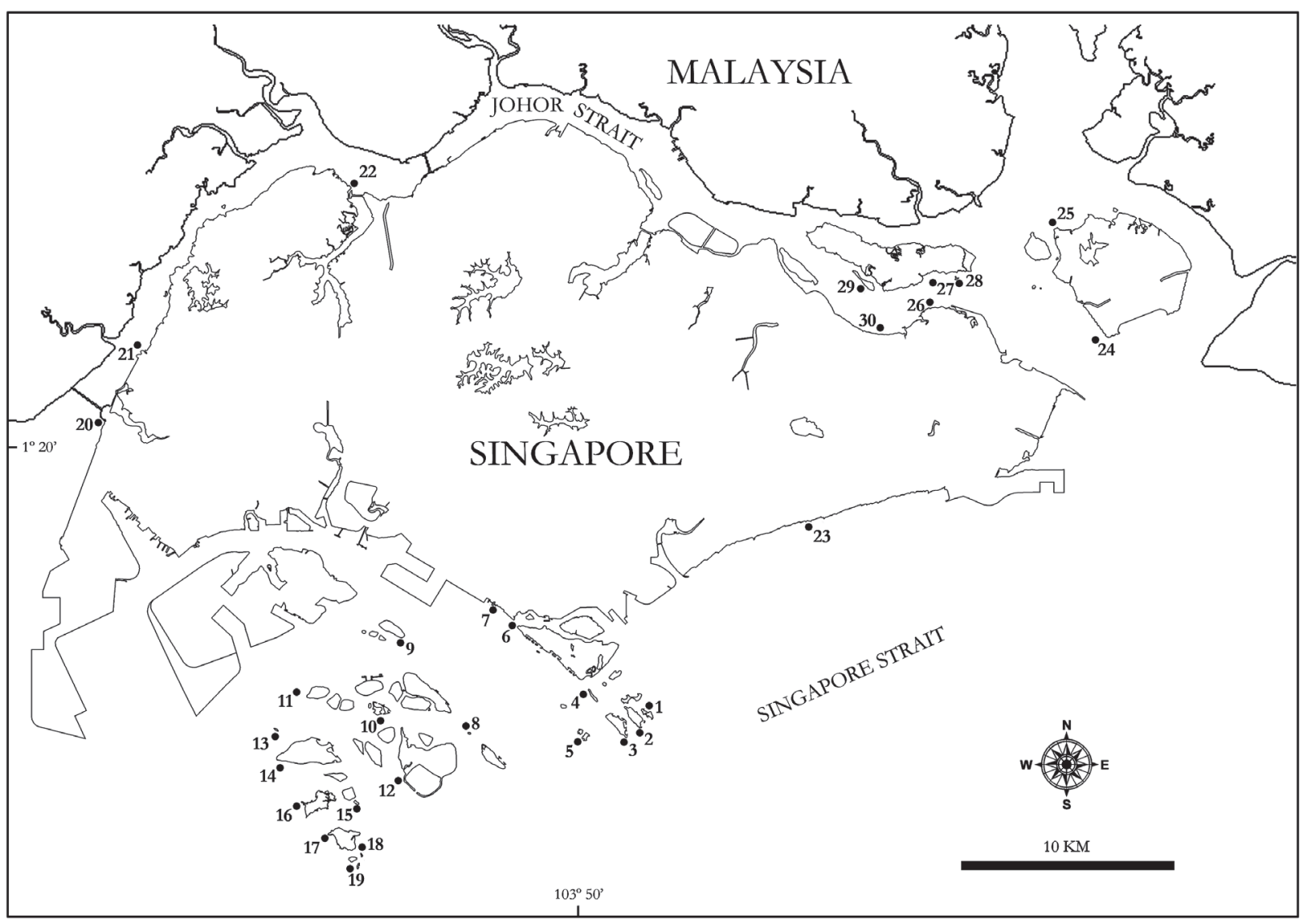

Fig. 1. Sampling localities of sponges in Singapore. 1. Kusu Island; 2. Lazarus Island; 3. St. John's Island; 4. Tekukor; 5. Sisters' Island; 6. Tanjong Rimau; 7. Labrador; 8. Pulau Jong; 9. Cyrene reef; 10. Pulau Hantu; 11. Sinki Fairway; 12. Pulau Semakau; 13. Pulau Salu; 14. Pulau Sudong; 15. Pulau Berkas; 16. Pulau Pawai; 17. Pulau Senang; 18. Pulau Biola; 19. Raffles Lighthouse; 20. Merawang Beacon; 21. W. Johor Strait; 22. Kranji; 23. East Coast; 24. Pulau Tekong; 25. E. Johor Strait; 26. Changi; 27. Pulau Sekudu; 28. Chek Jawa; 29. Pulau Ubin; 30. Pasir Ris. 
are typically three days with tides lower than $0.3 \mathrm{~m}$ Chart Datum (CD) in a month. Intertidal sponges were collected by hand during low spring tides (between 0 $\mathrm{m}$ and $0.5 \mathrm{~m}$ to $\mathrm{CD}$ ). Subtidal stations were sampled between May 2009 and June 2010 at depths of up to 30 $\mathrm{m}$. Of these 68 stations, 54 stations were sampled by SCUBA. The duration of each dive was about one hour. The remaining 14 subtidal stations were sampled with a naturalist's dredge (Holme and McIntyre, 1984) measuring $700 \mathrm{~mm} \times 300 \mathrm{~mm}$ with a mesh size of 5 $\mathrm{mm}$. Each haul was towed for about three minutes at a speed of 1 - 3 knots. At all stations, the shape, colour, texture and surface features of each specimen collected were recorded and photographs were made in situ immediately after collection before they were preserved in $70 \%$ ethanol. Voucher specimens were deposited at the Zoological Reference Collection (ZRC) at the Raffles Museum of Biodiversity Research (RMBR), National University of Singapore. Museum registration numbers are listed in Table 1. Type material is deposited at ZRC and NCB Naturalis (RMNH).

To examine skeletal architecture, paraffin-embedded sponge tissue was sectioned either by hand or by using a microtome. The sections were then cleared in Histoclearä or a phenol-xylene mixture and mounted in Dpexä on glass slides. Spicule preparations were made on a glass slide by dissolving a small piece of the specimen in a few drops of concentrated nitric acid over an alcohol flame. These were mounted either in Dpexäon glass slides for light microscopy or transferred onto brass stubs for scanning electron microscopy, following the method described in Hooper (2000). Spicule size range was estimated by measuring 25 spicules from one specimen, unless stated otherwise, and presented as lowest value range-mean-highest value range of length by lowest value range-meanhighest value range of width. The classification used here adheres to the current scheme described in the Systema Porifera (Hooper and van Soest, 2002). All species names were checked with the World Porifera Database (van Soest et al., 2011).

\section{Results}

A total of 197 sponge species from 16 orders, 50 families and 81 genera was recorded from Singapore (Table 1), of which 82 were identified to species, 99 to genus only, and 16 were provisionally assigned to known species which await comparison with type material. There were 23 new records for Singapore (indicated by an as- terisk; see Table 1). A total of 99 species were recorded from the intertidal zone, 143 species from the subtidal zone and 45 species occurred in both habitats. A total of 53 species were recorded exclusively from intertidal habitats and 98 species were confined exclusively to subtidal habitats. A new species of Forcepia (Forcepia) is described from Singapore in the Appendix. It is distinguished from its congeners in having the largest forceps so far recorded amongst its Indo-Pacific congeners.

\section{Discussion}

\section{Sponge diversity in Singapore}

The results from this study indicate a surprisingly high sponge diversity from a relatively small area that also embraces one of the world's largest container ports as well as significant oil refining and bunkering activity (see Chou, 2006). Many other sponge diversity studies conducted in the Indo-Pacific region recorded lower sponge diversity despite having surveyed larger areas, i.e., de Voogd et al. (1999) reported 151 species from the SW Sulawesi; Kritsanapuntu et al. (2001) reported 126 species of sponges from the Eastern Gulf of Thailand; Longakit et al. (2005) reported 33 species from Cebu, the Philippines; Putchakarn (2007) reported 45 species from Mo Ko Thale Tai National Park at Gulf of Thailand; 128 sponge species from the Mariana Islands (Kelly et al., 2002); de Voogd and Cleary (2008) reported 118 species from Jakarta Bay (Indonesia); and de Voogd et al. (2009) reported 168 species from the Derawan Islands (Indonesia). However, an objective comparison is impossible, since these studies vary considerably in the size of area surveyed, length of sampling period and sampling effort. Sponge diversity is most certainly to increase with sampling intensity, particularly in the Indo-Malayan Archipelago where even in well-studied areas, new species are still being discovered.

Nonetheless, the number of sponge species that occurs in Singapore is comparable to locations elsewhere in Southeast Asia, attesting to Singapore's central position in the biodiversity-rich Indo-Pacific region. The high number of species in Singapore can be also attributed to the relatively long sampling duration (over five years of regular surveys) and sampling effort, and also the inclusion of cryptic and sciophilous taxa. For example, Van Soest (2009) has shown that sponges inhabiting the undersides of coral rubble and crevices are not just juveniles but comprise a distinct 
assemblage of sponges. These have been largely overlooked in the past because they are usually cryptic and small, making sampling and identification difficult. A large number of new sponges (13 species) from such habitats were described recently from the otherwise well-studied Caribbean region (van Soest, 2009). More than ten sciophilous sponges from this study are undetermined species and await identification. These findings suggest that Singapore waters may still harbour a rich and under-studied sponge fauna that forms part of the high diversity triangle encompassing the Philippines, the Malay Archipelago and New Guinea (Briggs, 1987; Hoeksema, 2007). Two species recorded in this study, Terpios cruciata (Dendy, 1905) described from Sri Lanka and Tetrapocillon patbergquistae Fromont et al. 2010 described from Darwin (Australia) are new records to the South China Sea. The distribution range of these two species has been extended significantly from their previous known distribution. However, it is difficult to have an accurate picture of the distribution of Indo-Pacific sponges, as contemporary regional species inventories are still lacking from most parts of the South China Sea and Malay Archipelago (see Hooper et al., 2000). Many species have not been recorded since they were described in the 1900s. Reconciling early descriptions and type specimens with current material remains a daunting task.

Thirteen species were found to be relatively common and widespread in Singapore over a range of habitats, i.e., these species occurred at more than half of the localities (in descending order of occurrence); 1) Cinachyrella australiensis, 2) Spheciospongia sp. 'yellow cones', 3) Rhabdastrella globostellata, 4) Xestospongia testudinaria, 5) Spheciospongia cf. vagabunda, 6) Iotrochota baculifera, 7) Coelocarteria singaporensis, 8) Oceanapia sagittaria, 9) Chondrilla australiensis, 10) Biemna fortis, 11) Neopetrosia exigua, 12) Echinodictyum mesenterinum and 13) Mycale (Mycale) grandis. All these species have a wide Indo-Pacific distribution, and have been recorded in pristine as well as severely disturbed habitats (Bell and Smith 2004; Fromont et al. 2006; de Voogd et al., 2006) in the Gulf of Manaar, Thailand, Indonesia, Micronesia and Northern Australia. All the common sponge species were found in both intertidal and subtidal habitats except for Echinodictyum mesenterinum that was typically on reef slopes below the coral reef crest, and occurred in abundance at $15 \mathrm{~m}$ depth and below. Other examples of sponge species that can be considered common subtidally but absent intertidally include Craniella abracadabra, Jaspis splendens and Clathria (Wilsonella) foraminifera (see Table 1). However, half of the sponge species (99 out of 197 species) were observed to have a sporadic distribution having been recorded on less than three occasions during the whole survey. Such observations also concur with many sponge fauna studies (e.g. Hooper and Kennedy, 2002; Fromont, 2004; de Voogd et al., 2006).

The number of species observed varied considerably between each of the 30 localities (Table 1), ranging from two to 64 species. The ten richest localities are all located in the Singapore Strait except for an intertidal estuarine reef in the East Johor Strait (Fig. 1). Pulau Biola, a small rocky island with a fringing coral reef located at the southern extremity of the port limit within Singapore waters, possessed the highest sponge diversity with 64 species. The remaining eight localities high in sponge diversity were on small offshore islands typically with wide intertidal reef flats, fringing coral reefs, and steep reef slopes.

Substrata vary considerably, ranging from mud, sand, rock, coral rubble to live coral. Species such as Coelocarteria singaporensis, Oceanapia sagittaria and Ircinia irregularis burrow into muddy and sandy substrata, whereas Placospongia carinata, Mycale (Aegogropila) sulevoidea and Jaspis splendens are found on rocks. A high diversity of sponge fauna was found under rubble and boulders, living in crowded, encrusting and sciophilous communities. These sponges ranged from thin crusts of no more than several millimeters in thickness to slimy sponges, e.g., Acarnus primigenius, Forcepia (Forcepia) vansoesti sp. nov. (see description hereafter) and Hexadella indica. In addition, Chondrilla australiensis, Neopetrosia sp. 'blue' and Mycale (Mycale) grandis were usually found in gaps and crevices in-between living coral or over dead coral. Sponges are often most diverse below the reef crest of coral reefs (below $7 \mathrm{~m}$ depth), on the inclined reef slope, and flat seabed (observations were made at depths up to $27 \mathrm{~m}$ in this study). Their morphologies are more diverse, ranging from flexible whips, fingers and fans presumably adapted for coping with high currents, to soft tubes, vases and other shapes that predominate in silt-laden, turbid water (e.g., Clathria foraminifera, Thrinacophora cervicornis and Mycale (Zygomycale) parishi. A number of species with amorphous, bulbous, massive or spherical forms seemed to occur almost ubiquitously (e.g. Cinachyrella australiensis, Xestospongia testudinaria and Oceanapia sagittaria). 
Phototropic sponges with symbionts that need light to survive were usually found in shallow waters of less than $7 \mathrm{~m}$ depth, e.g. Chondrilla australiensis, Lendenfeldia chondrodes and Halichondria cartilaginea. However, massive and cup-shaped phototrophic sponge species (Carteriospongia foliascens, Phyllospongia papyracea and Strepsichordaia aliena) that are found in water with low turbidity elsewhere in Southeast Asia (de Voogd and Cleary, 2008) were absent here. Chronic high levels of sedimentation over the last 30-40 years have resulted in underwater visibility being reduced from $10 \mathrm{~m}$ recorded in the early 1960s to a contemporary average of $2 \mathrm{~m}$ (Chou, 1996). This appears to have reduced the depth at which coral can grow, resulting in a dead coral zone below 6-8 m. A thick layer of silt was observed at two localities, Labrador and P. Salu, which appear to have been adversely affected by land reclamation in the vicinity. Lower sponge diversity was apparent in these two locations; 19 species at Labrador and 21 species at $\mathrm{P}$. Salu.

In the East Johor Strait, an estuarine intertidal reef flat stood out in having a high diversity of sponges where 57 species were recorded. Considerable influence of seasonality on the occurrence of sponges was also observed based on monthly observations. Substantial changes in the abundance of Callyspongia sp. 'purple, branching', Haliclona sp. 'yellow, tubular' and Dysidea sp. were observed over time. These sponges grew quickly (e.g., Callyspongia sp. 'purple, branching' increased in length by more than $10 \mathrm{~cm}$ linearly within a month after settlement on substrata) but disappeared after a few months, only to reappear again the following year. These species might not have been recorded if only one survey was done at each site. Elsewhere in the Johor Straits, mangroves as well as muddy, sandy and rocky shores occur. In general the mangroves in Singapore were depauperate in sponge species. Between two and four intertidal species were recorded at Kranji, Changi and Pasir Ris. It would appear that mangroves in Singapore are quite unlike those in the Caribbean region. Rützler et al. (2000) reported 182 sponge species from Caribbean mangroves with a tidal range of less than $0.5 \mathrm{~m}$, and some 100 species occurred in mangroves habitats of Panama (Diaz, 2005).

The subtidal seabed of the Johor Strait was sampled using a naturalist's dredge because the water visibility was very poor (often less than $1 \mathrm{~m}$ ), which prevented sampling using SCUBA. From the dredging results, Pulau Tekong had the richest sponge diversity (13 spe- cies), followed by Merawang Beacon (five species) and P. Ubin (two species). No sponges were present at the six localities in the West Johor Strait based on dredging samples obtained. Suberites diversicolor and Terpios cruciata appeared to prefer estuarine conditions and were more common in the Johor Strait.

The sponge diversity in the Singapore Strait (146 species) was higher than in the Johor Strait (70 species). However, as the sampling effort was also greater in the Singapore Strait, more intense sampling effort may increase the number of species obtained and provides a better idea of the actual diversity in the Johor Strait. The rich sponge fauna (57 species) at the intertidal reef flat at the East Johor Strait indicates the possibility of a rich subtidal sponge community despite estuarine conditions, given that sponge diversity generally increases with depth (e.g. Zea, 1993; de Voogd et al., 1999; Bell and Barnes 2000; Fromont, 2006). Interestingly, there were only 11 species in common between Pulau Biola and E. Johor Strait, suggesting that the two habitats harboured rather different sponge assemblages. Whilst P. Biola was mainly associated with typical coral reef species, sponges observed in the Johor Strait appear to be adapted to a more turbid, estuarine conditions.

\section{Intertidal sponges}

Approximately half of Singapore shallow water sponge species (99 out of 197 species) were found in the lower half of the intertidal zone (Table 1). Amongst the few studies done on intertidal sponge fauna in the Indo-Pacific, Berquist and Tizard (1967) recorded 19 species from Darwin (Australia); Esmero (1978) recorded 25 species from Cebu (Philippines); Barnes (1999) recorded 33 species from Quirimba Archipelago (Mozambique, East Africa); and Fromont (2004) recorded 29 species (from a single station) from Dampier Archipelago (Western Australia). Interestingly, more than half (ten) of the intertidal sponge species reported by Bergquist and Tizard (1967) from Darwin occurred intertidally in Singapore. They are: 1) Ircinia irregularis; 2) Pseudoceractina purpurea (as Psammaplysilla purpurea); 3) Lamellodysidea herbacea (as Dysidea herbacea); 4) Neopetrosia exigua (as Xestospongia exigua); 5) Haliclona cymaeformis (as Sigmadocia symbiotica); 6) Coelocarteria singaporensis; 7) Iotrochota baculifera; 8) Clathria reinwardti; 9) Spheciospongia vagabunda (as Spirastrella vagabunda) and 10) Cinachyrella australiensis. Of the intertidal species, 53 
species appear to be exclusively intertidal in habit (Table 1). These observations suggest that there might be distinct assemblages of sponges in Singapore waters, i.e., species that can be found both intertidally and subtidally, and species that can only occur subtidally and cannot survive exposure to air. There are many genera and families of sponges restricted to either shallow or deeper waters with apparently very little in common between these communities (BouryEsnault and Lopes, 1985). A similar situation may exist for intertidal and subtidal shallow sponges. Sponge species are generally unable to survive long exposure to air (see Rützler, 1995). During emersion, intertidal sponges are subjected to adverse conditions of diminished oxygen and food supplies normally provided by circulation of seawater inside the sponge. Further, the increase in salinity by evaporation of interstitial water retained in the animal, rise in temperature, and exposure to ultraviolet radiation (Rützler, 1995), all contribute to emersion stress. When the sponge is returned to water, the channels of the aquiferous system may then be blocked by air so that the circulation of water is not re-established. There might be major physiological differences between intertidal and subtidal sponges that allow intertidal sponges to survive emersion and harsh environmental conditions such as desiccation and high temperature.

\section{Subtidal sponges}

The majority of the sponge fauna (143 out of 197 species) in Singapore were recorded subtidally, with 98 species confined to subtidal habitats. Most of these sponges were recorded on fringing reefs in the Singapore Strait. Interestingly, the species composition was quite different from those on artificial substrata. The common fouling sponge species recorded on navigational buoys around the localities in this study were Suberites diversicolor, Tethya robusta, Mycale (Carmia) sp. 'red, encrusting', Mycale (Zygomycale) parishi, Amorphinopsis excavans and Cladocroce sp. 'massively encrusting' (Lim et al., 2009). These are different from the common sponges found on natural substrata in this study, comprising less than $25 \%$ of the 62 fouling sponge species on navigation buoys (Lim et al., 2009). Such observations support the recent findings of Smith and Rule (2002), Qvarfordt et al. (2006) and Lim et al. (2009) that artificial structures may not necessarily be surrogates for natural hard substrata. Sponge assemblages appear to be distinct in intertidal, subtidal and artificial habitats.

\section{Acknowledgements}

We thank the National Parks Board (Ministry of National Development, Singapore) for providing the necessary funding to ensure the success of this project. We are especially grateful to Miss Yang Shufen, Miss Linda Goh, Mr Wong Tuan Wah and Dr Nigel Goh at the National Biodiversity Centre, National Parks Board for valuable assistance rendered before and during the course of the survey. This study also benefited greatly from discussions with Dr Rob van Soest and Mrs Elly Beglinger (Zoological Museum, Amsterdam); Mr Andrew Cabrinovic and Ms Clare Valentine (The Natural History Museum, London); Dr Giuliano Doria, Mr Massimo Perri and Ms Maria Bruna Invernia (Museo Civico di Storia Naturale 'Giacomo Doria', Genoa), Mr Tan Siong Kiat (Raffles Museum of Biodiversity Research) all of whom freely and kindly assisted us in locating sponge types and specimens in their respective care. The first author acknowledges the Martin Fellowship from the National Museum of Natural History, Leiden. The second author received support from the SYNTHESYS Project (http://www.synthesys. info/) financed by European Community Research Infrastructure Action under the FP6 'Structuring the European Research Area' Programme. We are grateful to two anonymous reviewers for their constructive comments. Any errors remain our own.

\section{References}

Barnes DKA. 1999. High diversity of tropical intertidal zone sponges in temperate, salinity and current extremes. African Journal of Ecology 37: 424-434.

Becking LE, Lim SC. 2009. A new Suberites (Demospongiae: Hadromerida: Suberitidae) from the tropical Indo-West Pacific. Zoologische Mededelingen, Leiden 83: 853-862.

Bell JJ, Barnes DKA. 2000. A sponge diversity centre within a marine 'island'. Hydrobiologia 440: 55-64.

Bell JJ, Smith D. 2004. Ecology of sponge assemblages (Porifera) in the Wakatobi region, south-east Sulawesi, Indonesia: Richness and abundance. Journal of the Marine Biological Association of the United Kingdom 84: 581-591.

Bergquist PR, Tizard CA. 1967. Australian intertidal sponges from the Darwin area. Micronesica 3: 175-202.

Boury-Esnault N, Lopes MT. 1985. Les démosponges littorales de l'Archipel des Acores. Annals de L'Institute Océanographique. Paris 61: 149-225.

Briggs JC. 1987. Biogeography and plate tectonics. Developments in paleontology and stratigraphy. Amsterdam: Elsevier.

Carter HJ. 1883. Contributions to our knowledge of the Spongia. Annals and Magazine of Natural History (5) 12: 308-329.

Chou LM. 1996. Response of Singapore reefs to land reclamation. Galaxea 13: 85-92

Chou LM. 2006. Marine habitats in one of the world's busiest harbours. Pp. 377-391 in: Wolanski E, ed., The Environment in Asia Pacific Harbour. Dordrecht: Springer.

Chou LM, Wong FJ. 1985. Reef community structure of Pulau Salu. Pp. 285-290 in: Delesalle B, Galzin R, Salvat B, eds, Proceedings of the Fifth Coral Reef Congress, Tahiti. Antenne Museum-EPHE: Moorea, French Polynesia.

Chuang SH. 1961. On Malayan Shores. Singapore: Muwu Shosa. 
Chuang SH. 1973. Life of the seashore. Pp. 150-174 in: Chuang SH, ed., Animal Life and Nature in Singapore. Singapore: Singapore University Press.

Chuang SH. 1977. Ecology of Singapore and Malayan coral reefs - Preliminary classification. Pp. 55-63 in: Taylor DL, ed., Proceedings of Third International Coral Reef Symposium. Vol. 1: Biology. Miami (Florida): Rosential School of Marine and Atmospheric Science.

Dendy A. 1905. Report on the sponges collected by Professor Herdman, at Ceylon, in 1902. Pp. 57-246, pls. I-XVI, in: Herdsman WA, ed., Report to the Government of Ceylon on the Pearl Oyster Fisheries of the Gulf of Manaar 3 (Supplement 18). London: Royal Society.

Diaz MC. 2005. Common sponges from shallow marine habitats from Bocas del Toro region, Panama. Caribbean Journal of Science 41: 465-475.

Dragnewitsch P. 1906. Spongien von Singapore. Zoologische Jahrbucher. Abteilung fur Systematik 23: 439-448.

Esmero MLA. 1978. Intertidal sponge fauna on artificial substrates in Cebu Harbor. Philippines Scientist 15: 76-95.

Fromont J. 2004. Porifera (sponges) of the Dampier Archipelago, Western Australia: habitats and distributions. Records of the Western Australia Museum Supplement 66: 69-100.

Fromont J, Alvarez B, Gomez O, Roberts E. 2010. Tetrapocillon (Demospongiae: Poecilosclerida: Guitarridae) in Australia, with the description of a new species. Records of the Western Australian Museum 26: 68-80.

Fromont J, Vanderlift MA, Kendrick GA. 2006. Marine sponges of the Dampier Archipelago, Western Australia: patterns of species distributions, abundance and diversity. Biodiversity and Conservation 15: 3731-3750.

Gray JE. 1873. On two new free sponges from Singapore. Annals and Magazine of Natural History (4) 11(63): 234-235.

Haeckel E. 1872. Die Kalkschwämme. 1: 1484; 2: 1418; 3: pls. 1-160. Eine Monographic in zwei Bänden Text und einem Atlas mit 60 Tafeln Abbildungen. Berlin: G. Reimer.

Hardwicke T. 1822. Description of a Zoophyte commonly found about the coast of Singapore Island (Spongia patera). Asiatic Researches 14: 180-181.

Hoeksema BW. 2007. Delineation of the Indo-Malayan Centre of Maximum Marine Biodiversity. The Coral Triangle. Pp. 117-178 in: Renema W, ed., Biogeography, Time, and Place: Distributions, Barriers, and Islands. Dordrecht: Springer.

Holme NA, McIntyre AD, eds, 1984. Methods for the study of marine benthos. IBP Hand Book 16. Oxford: Blackwell Scientific Publications.

Hooper JNA. 2000. 'Sponguide'. Guide to sponge collection and identification. [available at http://www.qmuseum.qld. gov.au/organisation/sections/SessileMarineInvertebrates]

Hooper JNA, Kennedy JA. 2002. Small-scale patterns of sponge biodiversity (Porifera) on Sunshine Coast reefs, eastern Australia. Invertebrate Systematics 16: 637-653.

Hooper JNA, Kennedy JA, List-Armitage SE, Cook SD, Quinn R. 1999. Biodiversity, species composition and distribution of marine sponges in northeast Australia. Memoirs of the Queensland Museum 44: 263-274.

Hooper JNA, Kennedy JA, van Soest RWM. 2000. Annotated checklist of sponges (Porifera) of the South China Sea region. The Raffles Bulletin of Zoology, Supplement 8: 125207.
Hooper JNA, van Soest RWM, eds. 2002. Systema Porifera: A Guide to the Classification of Sponges, Volume 1. New York: Kluwer Academic/Plenum Publishers.

Kelly M, Hooper JNA, Paul V, Pauley G, van Soest RWM, de Weerdt W. 2002. Taxonomic inventory of sponges (Porifera) of the Mariana Islands. Micronesica Supplement 6: 100-120.

Kritsanapuntu S, Chaitanawisuti N, Yeemin T, Putchakan S. 2001. First investigation on biodiversity of marine sponges associated with reef coral habitats in the Eastern Gulf of Thailand. Asian Marine Biology 18: 105-115.

Lim SC, Tan KS. 2008. A new species of Tethycometes Sarà, 1994 (Porifera: Hadromerida: Tethyidae) from Singapore. Zootaxa 1841: 65-68.

Lim SC, de Voogd NJ, Tan KS. 2009. Fouling sponges (Porifera) on navigational buoys from Singapore waters. The Raffles Bulletin of Zoology Supplement 22: 41-58.

Longakit MBA, Sotti FB, Kelly M. 2005. The shallow water marine sponges (Porifera) of Cebu, Philippines. Science Diliman 17(2): 52-74.

Putchakarn S. 2007. Species diversity of marine sponges dwelling in corals reefs in Had Khanom - Mo Ko Thale Tai National Park, Nakhon Si Thammarat Province, Thailand. Journal of the Marine Biological Association of the United Kingdom 87: 1635-1642.

Qvarfordt S, Kautsky H, Malm T. 2006. Development of fouling communities on vertical structures in the Baltic Sea. Estuarine, Coastal and Shelf Science 67: 618-628.

Ridley SO. 1884. Notes on sponges, with description of a new species. Annals and Magazine of Natural History (5) 14(81): 183-187.

Rützler K. 1995. Low-tide exposure of sponges in Caribbean mangrove community. P.S.Z.N. Marine Ecology 16: 165-179.

Rützler K, Diaz MC, van Soest RWM, Zea S, Smith KP, Alvarez B, Wulff JL. 2000. Diversity of sponge fauna in mangrove ponds, Pelican Cays, Belize. Atoll Research Bulletin 476: 229-248.

Smith SDA, Rule MJ. 2002. Artificial substrata in a shallow sublittoral habitat: do they adequately represent natural habitats of local species pool? Journal of Experimental Marine Biology and Ecology 277: 25-41.

Soest RWM van. 1989. The Indonesian sponge fauna: a status report. Netherlands Journal of Sea Research 23: 223-230.

Soest RWM van. 1990. Shallow-water reef sponges of eastern Indonesia. Pp. 302-308 in: Rützler K, ed., New Perspectives in Sponge Biology. Washington, D.C.: Smithsonian Institution Press.

Soest RWM van. 1994. Demosponge distribution patterns. Pp. 213-223 in: van Soest RWM, van Kempen Th. MG, Braekman JC, eds, Sponges in Time and Space. Rotterdam: Balkema.

Soest RWM van. 2002. Family Coelosphaeridae Dendy, 1922. Pp. 528-546 in: Hooper JNA, Van Soest RWM, eds, Systema Porifera. A guide to the classification of sponges, 1 . New York, Boston, Dordrecht, London, Moscow: Kluwer Academic/ Plenum Publishers.

Soest RWM van. 2009. New sciophilous sponges from the Caribbean (Porifera: Demospongiae). Zootaxa 2107: 1-40.

Soest RWM van, Boury-Esnault N, Hooper JNA, Rützler K, de Voogd NJ, Alvarez B, Hajdu E, Pisera AB, Manconi R, Schoenberg C, Janussen D, Tabachnick KR, Klautau M, Piston B, Kelly M. 2011. World Porifera database. Available online at http://www.marinespecies.org/porifera. [visited 25 January 2011] 
Voogd NJ de, Cleary DFR. 2008. An analysis of sponge diversity and distribution at three taxonomic levels in the Thousands Islands/Jakarta Bay reef complex, West-Java, Indonesia. Marine Ecology 29: 205-215.

Voogd NJ de, Cleary DFR. 2009. Variation in sponge composition among Singapore reefs. The Raffles Bulletin of Zoology Supplement 22: 59-67.

Voogd NJ de, Becking LE, Cleary DFR. 2009. Sponge community composition in the Derawan Islands, NE Kalimantan, Indonesia. Marine Ecology Progress Series 396: 169180.

Voogd NJ de, Cleary DFR, Hoeksema BW, Noor A, van Soest RWM. 2006. Sponge beta diversity in the Spermonde Archi- pelago, SW Sulawesi, Indonesia. Marine Ecology Progress Series 309: 131-142.

Voogd NJ de, van Soest RWM, Hoeksema BW. 1999. Crossshelf distribution of southwest Sulawesi reef sponges. Memoirs of the Queensland Museum 44: 147-154.

Zea S. 1993. Recruitment of Demosponges (Porifera, Demospongiae) in rocky and coral reef habitats of Santa Mart, Colombian Caribbean. Marine Ecology 14: 1-21.

Received: 4 July 2011

Revised and accepted: 23 September 2011

Published online: 31 January 2012

Editor: R.W.M. van Soest 


\section{Appendix}

\section{Systematics}

Class: Demospongiae

Order: Poecilosclerida

Suborder: Myxillina

Family: Coelosphaeridae Dendy, 1922

Genus: Forcepia Carter, 1874

Subgenus: Forcepia Carter, 1874

Forcepia (Forcepia) vansoesti sp. nov. (Figs 2-3)

Holotype. ZRC.POR.0126, Singapore, Singapore Strait, P. Biola (western reef), $1^{\circ} 9.856^{\prime} \mathrm{N} 103^{\circ} 44.449$ 'E, $10 \mathrm{~m}$ depth, 5.iii. 2010, coll. S.C. Lim. Paratype. ZRC. POR.0271, Singapore, Singapore Strait, Kusu Island (eastern reef), $1^{\circ} 13.469^{\prime} \mathrm{N} 103^{\circ} 50.902^{\prime} \mathrm{E}, 12 \mathrm{~m}$ depth, 19.ix. 2010, coll. S.C. Lim. Paratype. RMNH POR. 6136, Singapore, Singapore Strait, Kusu Island (southeastern reef), $1^{\circ} 13.045^{\prime} \mathrm{N} 103^{\circ} 51.328^{\prime} \mathrm{E}, 10 \mathrm{~m}$ depth, 8.i.2010, coll. S.C. Lim.

Description. Sponge consists of thin, translucent, hollow, fistules (both blind-ended and with oscules at the apex) arising from thin encrustations, typically about $1 \mathrm{~mm}$ in thickness and not more than $5 \mathrm{~cm}$ wide (Fig. 2a). Numerous fistules, often more than ten in number, are irregularly distributed, between 3-10 $\mathrm{mm}$ apart from each other. Fistules are usually 4-5 $\mathrm{mm}$ in height and $2-3 \mathrm{~mm}$ in diameter both at the base and at the apex. Oscules are typically $2 \mathrm{~mm}$ in diameter. Consistency soft, fragile, and slightly flexible. Reticulation of skeleton is visible to the naked eye in situ. Found on hard substrata, e.g., coral rubble and rock. Colour bright orange in living specimens. Pale light brown in alcohol.

Skeleton. Thick irregularly bundles of spicules, 60$220 \mu \mathrm{m}$ in diameter arise from the base and fan out at the surface where they become dispersed tangentially, forming an irregular ectosomal skeleton with spicule bundles 40-60 $\mu \mathrm{m}$ in diameter (Fig. 2b). Fistules, thin, single spicule layer, irregular, vaguely intercrossing single and paucispicular bundles (Fig. 2c).

Spicules. Tylotes, forceps and arcuate isochelae. Tylotes (Fig. 3a), 285-354.4-390 $\mu \mathrm{m} \times 6-7.1-9 \mu \mathrm{m}$. Smooth, slightly bent, prominent tyles.

Forceps (Fig. 3b), 210-264.4-288 $\mu \mathrm{m} \times 6-7.8-10 \mu \mathrm{m}$, distance between the legs (25-30.5-40 $\mu \mathrm{m})$. Heavily spined, with teethed apices; rare. The total number of forceps did not exceed 20 in $3 \times 3 \mathrm{~mm}$ size crust or 2 $\times 4 \mathrm{~mm}$ size fistules in all materials examined. Arcuate isochelae I (Fig. 3c) 1) 28-28.9-32.5 $\mu \mathrm{m}$ (twisted); Arcuate isochelae II (Fig. 3d) 17.5-18.9-20 $\mu \mathrm{m}$ (normal). The large size chelae are predominantly twisted and normal-shaped chelae at this size category is rare or absent in the types. The smaller category chelae are all normal-shaped.

Ecology. On coral rubble and in crevices, subtidal. Depth range 3-20 m.

Etymology. The species is named in honour of $\mathrm{Dr}$ Rob van Soest, who has inspired and contributed much to modern sponge taxonomy.

Remarks. This species is clearly a Forcepia species in having forceps. The absence of basal acanthostyles would place this species in the subgenus Forcepia, as the other subgenus Leptolabis is characterized by having a hymedesmioid skeleton and acanthostyles. The myxilline forceps with its rugose or spined surface is a unique spicule type. This was interpreted as a synapomorphy for this genus of sponge although both subgenera have different skeletal structure (van Soest, 2002). With regards to the absence of reticulate skeleton of $F$. $(F$.) vansoesti sp. nov., there are two other species, $F$. $(F$.) colonensis and $F$. $(F$.) minima, which also lack a reticulate skeleton. Five Forcepia (Forcepia) species have been described from Indo-Pacific: 1) F. (F.) mertoni Hentschel, 1912 from the Indonesia; 2) $F$. (F.) stephensi Dendy, 1922 from the Seychelles; 3) F. (F.) lissa (de Laubenfels, 1954) from the Micronesia; 4) $F$. $(F$.) foresti Lévi and Lévi, 1989; and 5) F. (F.) koltuni Lévi \& Lévi, 1989, both from the Philippines. Two species are found in the warm temperate region of Western Pacific Ocean: $F$. $(F$.) volsella Topsent, 1928 and $F$. (F.) solustylota Hoshino, 1977, both described from areas in Japan influenced by the warm Central Kuroshio Current.

The key distinguishing character of the new species is the presence of large forceps that are nearly $300 \mu \mathrm{m}$ in length (210-264.4-288 $\mu \mathrm{m} \times 6-7.8-10 \mu \mathrm{m})$. All Forcepia (Forcepia) species described previously from the Indo-Pacific have forcipes less than $100 \mu \mathrm{m}$ in length, with $F$. (F.) mertoni having the largest forceps (up to $88 \mu \mathrm{m}$ in length) amongst these species.

No Forcepia (Forcepia) species described to date from the adjacent Indian Ocean and Pacific Ocean has forceps larger than $100 \mu \mathrm{m}$. Only $F$. $(F$.) agglutinans Burton, 1933 from Stil Bay, Africa and $F$. $(F$.) volsella Topsent, 1928 from Japan have forceps up to $100 \mu \mathrm{m}$ in size. However, there are several species from the 

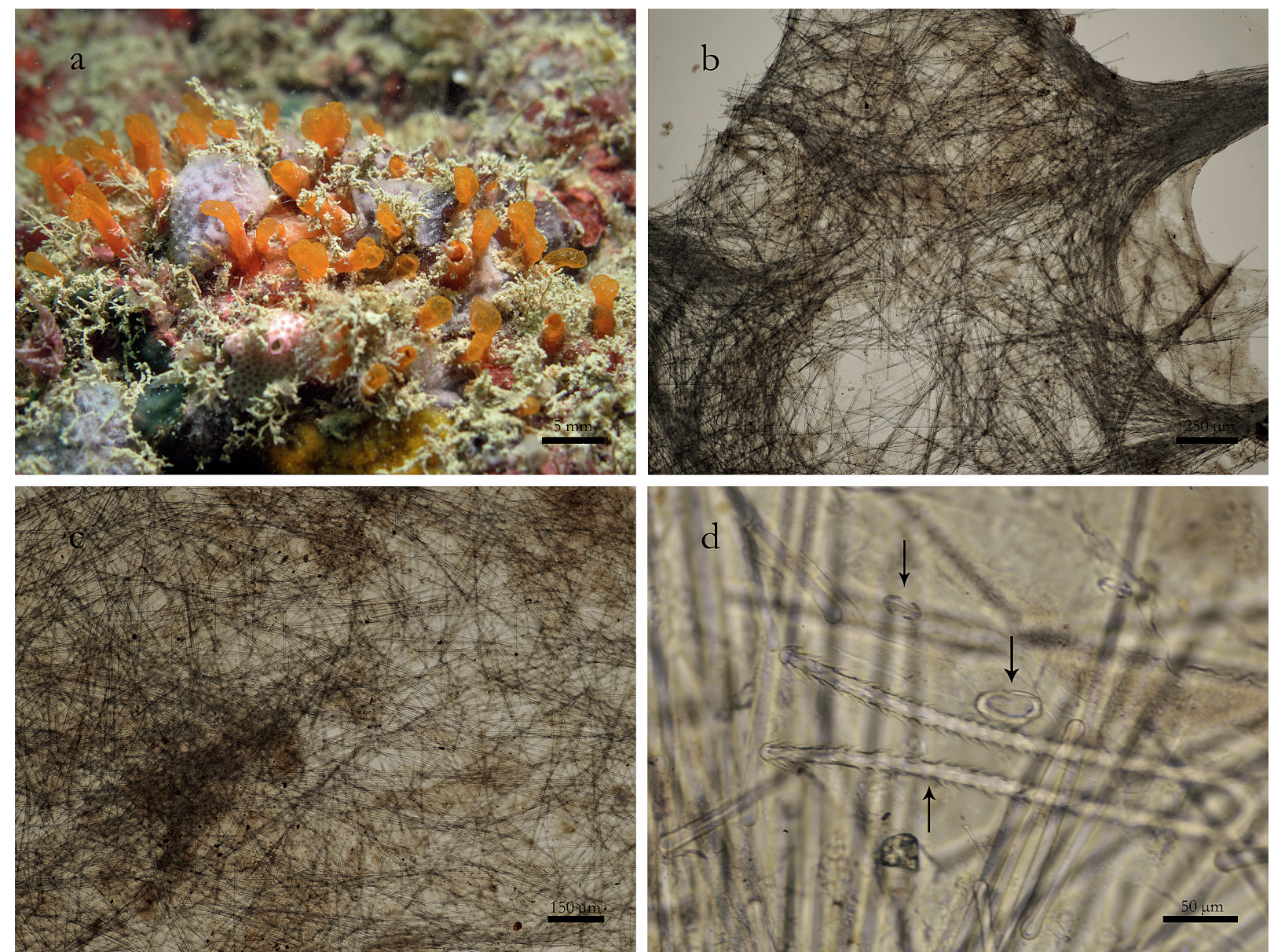

Fig. 2. Forcepia (Forcepia) vansoesti sp. nov. (Holotype POR.ZRC.0216). a) Forcepia (Forcepia) vansoesti sp. nov. in situ. b) Skeleton of encrustation, surface view. c) Skeleton of fistule, surface view. d) Microscleres in encrustation skeleton; the forceps and two size arcuate isochelae are indicated by arrows.

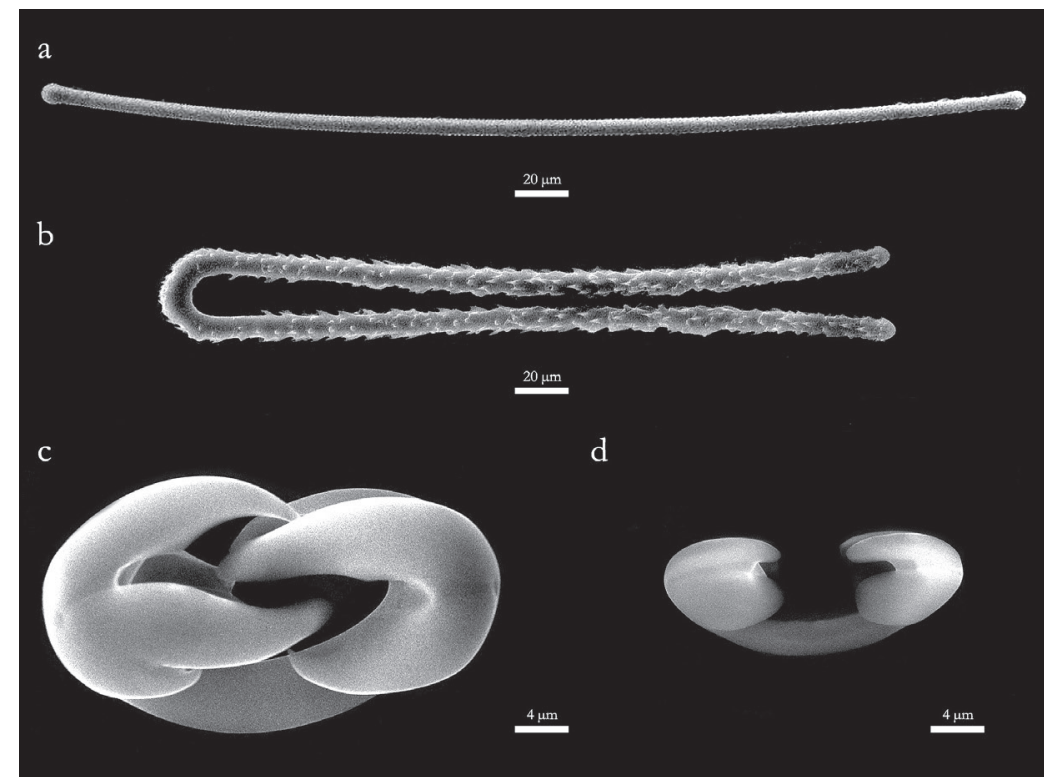

Fig. 3. SEM images of Forcepia (Forcepia) vansoesti sp. nov. spicules. a) Tylote. b) Spined forceps. c) Arcuate isochelae (large, twisted). d) Arcuate isochelae (small, normal-shaped). 
Atlantic Ocean with large forceps that are more than $200 \mu \mathrm{m}$ in length; 1) $F$. (F.) colonensis Carter, 1874 (260 um); 2) F. (F.) forcipis (Bowerbank, 1866) (351$432 \mu \mathrm{m} \times 3-4 \mu \mathrm{m}$ ); and 3) $F$. (F.) trilabis (Boury-Esnault, 1973) $(209-258 \mu \mathrm{m} \times 3.5 \times 4.5 \mu \mathrm{m})$.

Amongst the Caribbean Forcepia (Forcepia) species with large forceps, Forcepia (F.) forcipis is distinct in having the largest forceps in the genus with three size categories of forceps. Forcepia (F.) trilabis is distinct in having a smaller category of smaller forceps $(40 \mu \mathrm{m} \times 1 \mu \mathrm{m})$. Forcepia $(F$.) colonensis has somewhat similar spiculation to the new species: forceps $(200-260 \mu \mathrm{m} \times 3.5-4.5 \mu \mathrm{m})$, arcuate isochelae I (20-38 $\mu \mathrm{m})$, arcuate isochelae II (15-20 $\mu \mathrm{m})$, and tylotes (330-360 $\mu \mathrm{m} \times 4-7 \mu \mathrm{m})$. However, the new species can be distinguished from $F$. $(F$.) colonensis in having one size category of twisted arcuate isochelae, normal instead of reduced alae, and considerably thicker forceps at 6-7.8-10 $\mu \mathrm{m}$. While the new species appear to be a shallow-water species found at 3-20 m depth, F. colonensis is a deep sea species found at depth of over $600 \mathrm{~m}$ (363 fathoms).

Despite the new species having large forceps, it is amongst the smallest species found in the Indo-Pacific in terms of overall size. The new species is only slightly larger than $F$. (F.) fistulosa, the latter consists of tiny hollow encrustations of approximately $0.5-1 \mathrm{~mm}$ thickness and maximum of $2 \mathrm{~cm}^{2}$ in widest expansion, with up to three fistules of $2 \mathrm{~mm}$ diameter and $4-5 \mathrm{~mm}$ high. Both species have very similar habit but have very different spiculations. Forcepia ( $F$.) fistulosa has only one category of chelae (15-22.3-24 $\mu \mathrm{m})$, and two size categories of forceps that are much smaller (size 54-68.5-91 $\mu \mathrm{m}$ and 27-39.5-48 um). Interestingly, the new species is the only Forcepia species recorded from Singapore waters, adding to the existing five species previously described from the Indo-Pacific. It is also the only Forcepia species in the Indo-Pacific with twisted chelae, a character that is shared by $F$. (F.) fistulosa and $F$. (F.) grandisigmata, both described from the Caribbean. Another interesting character is the small number of forceps in each individual. In some specimens, less than three forceps could be observed on the spicule preparation slide. It is difficult to imagine that these large forceps actually serve any skeletal function in the sponge.

\section{On-line supplementary material (SI)}

S1. Localities, and geographical coordinates of 58 stations in the intertidal sponge fauna survey.

S2. Localities, and geographical coordinates of 68 stations in the subtidal sponge fauna survey. 


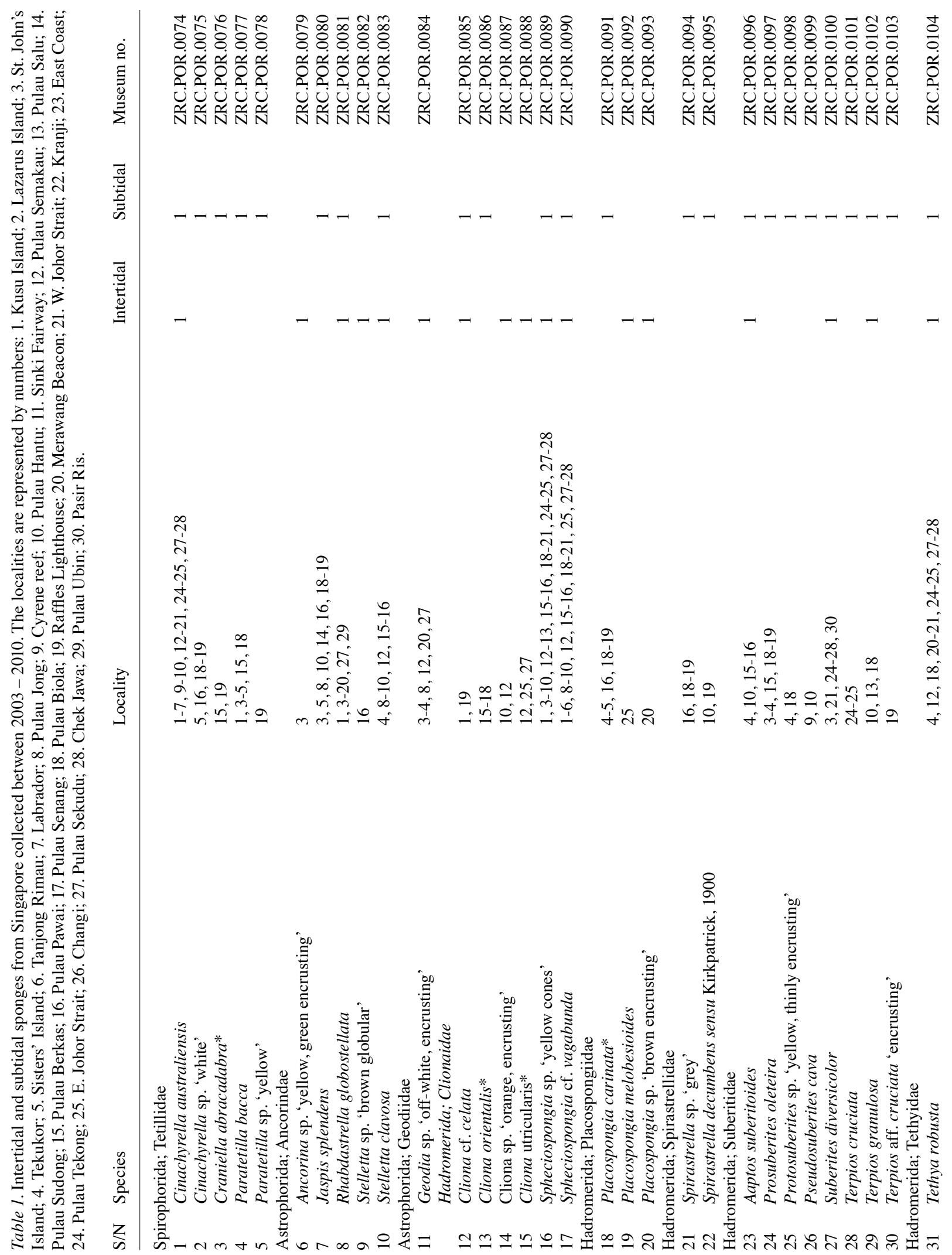




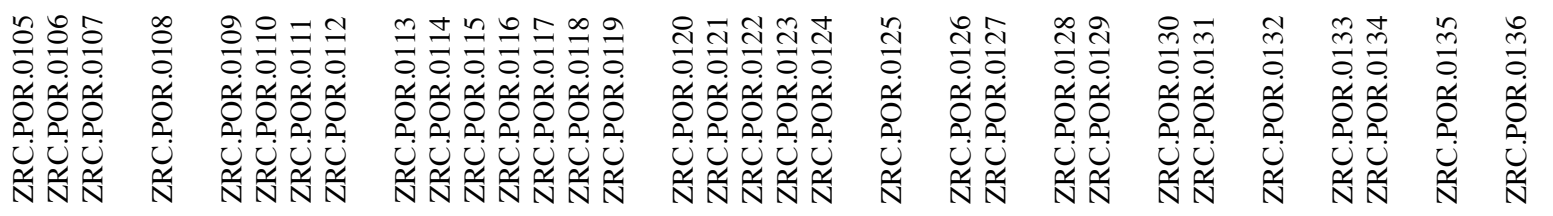
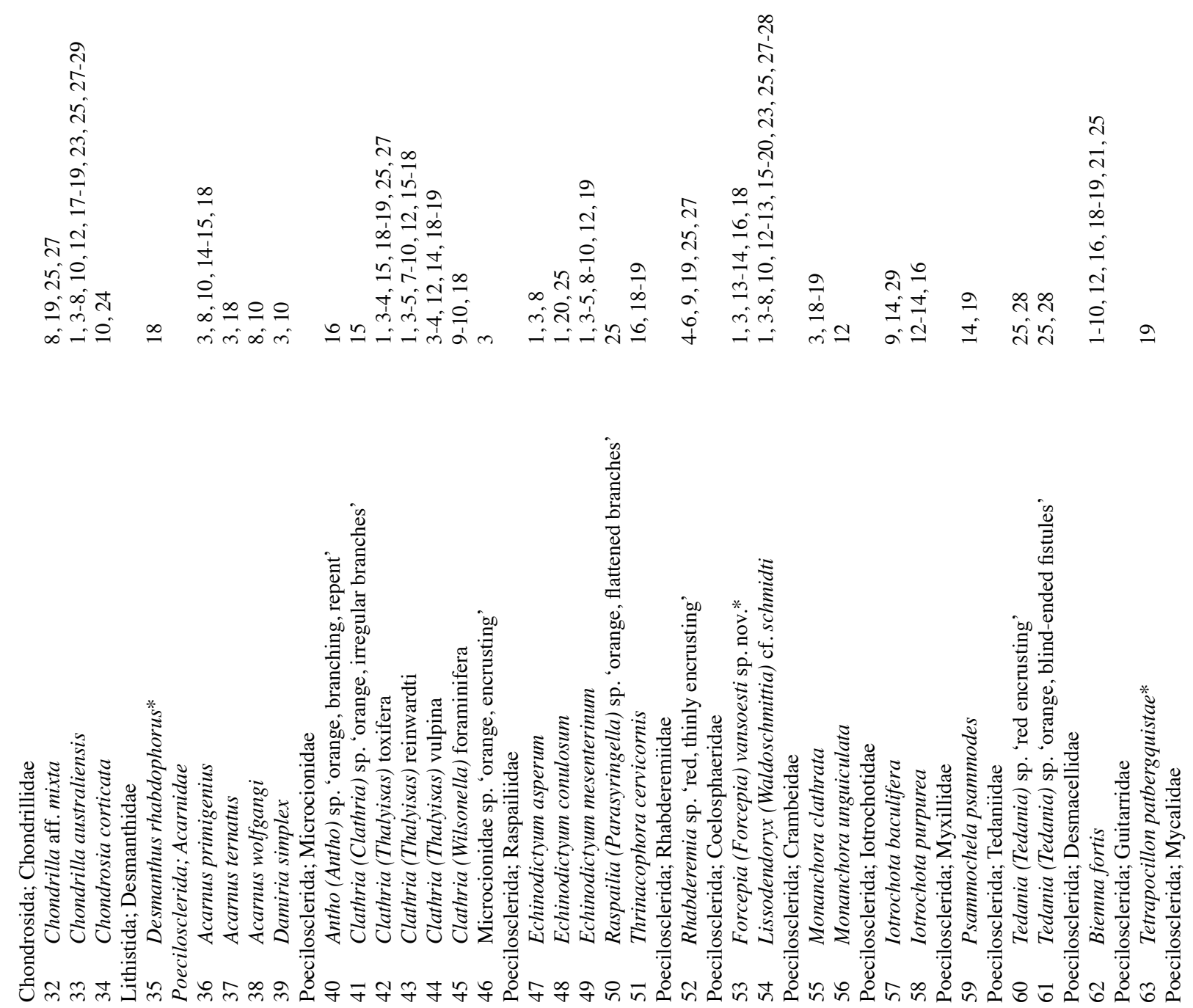

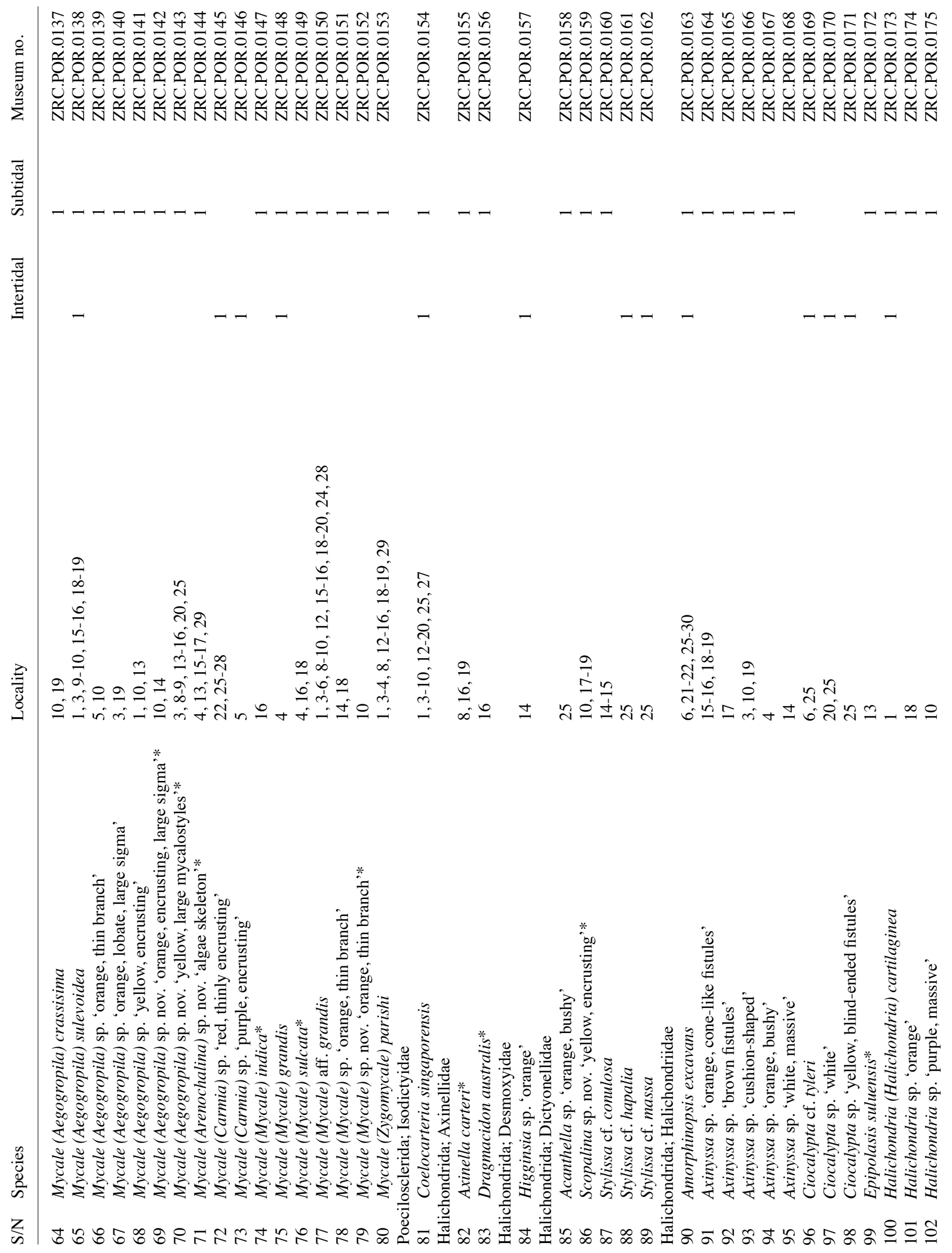


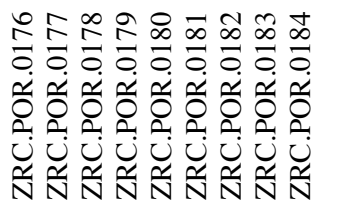

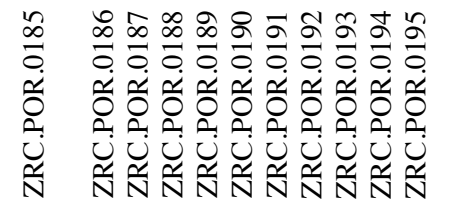

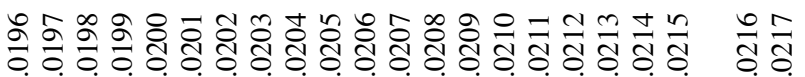

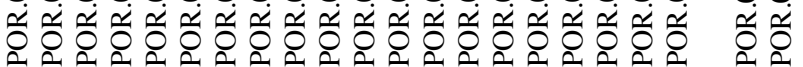

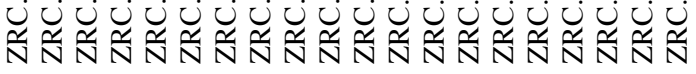

焉迹

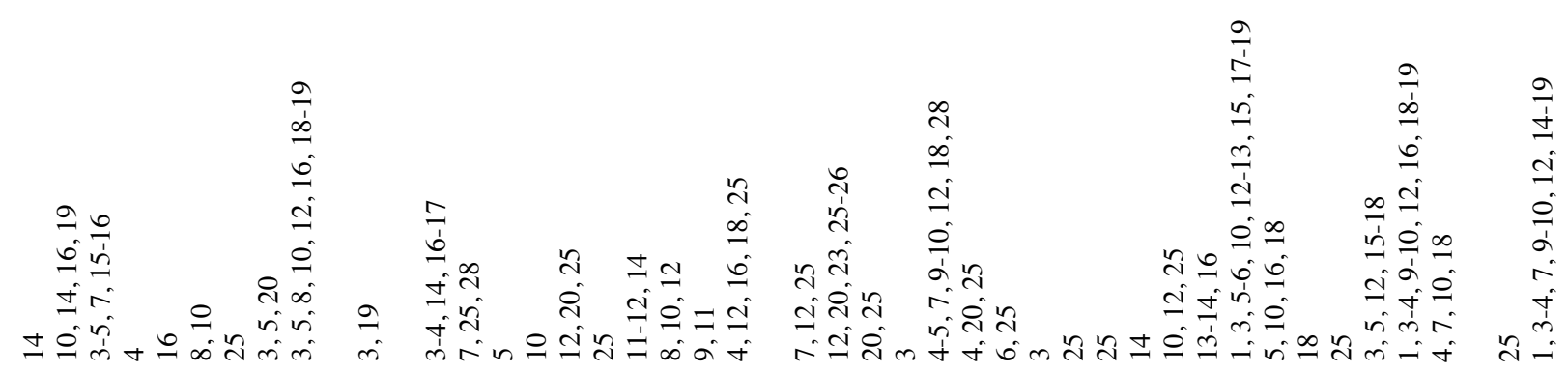

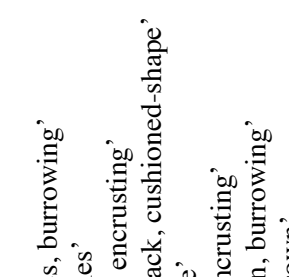

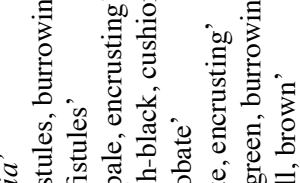

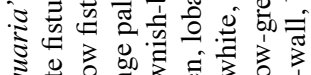

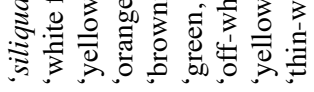

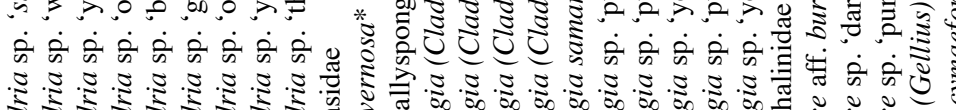

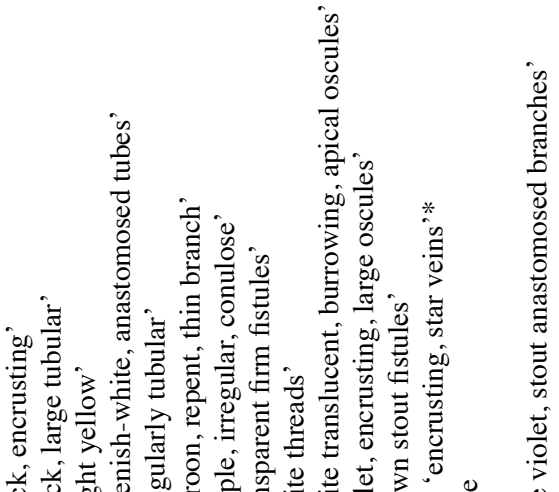

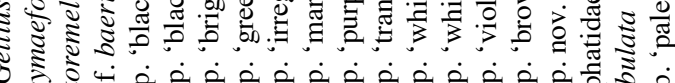

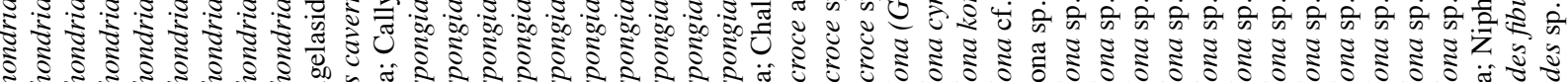

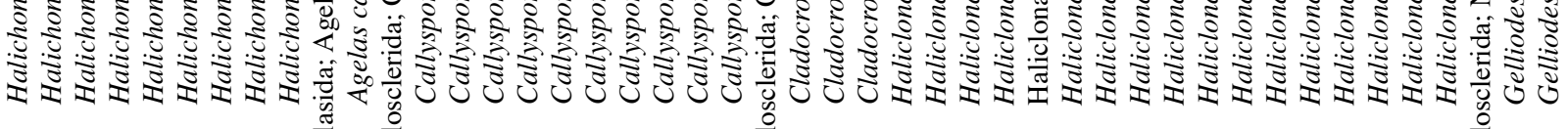

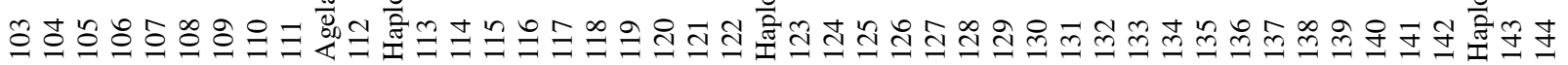



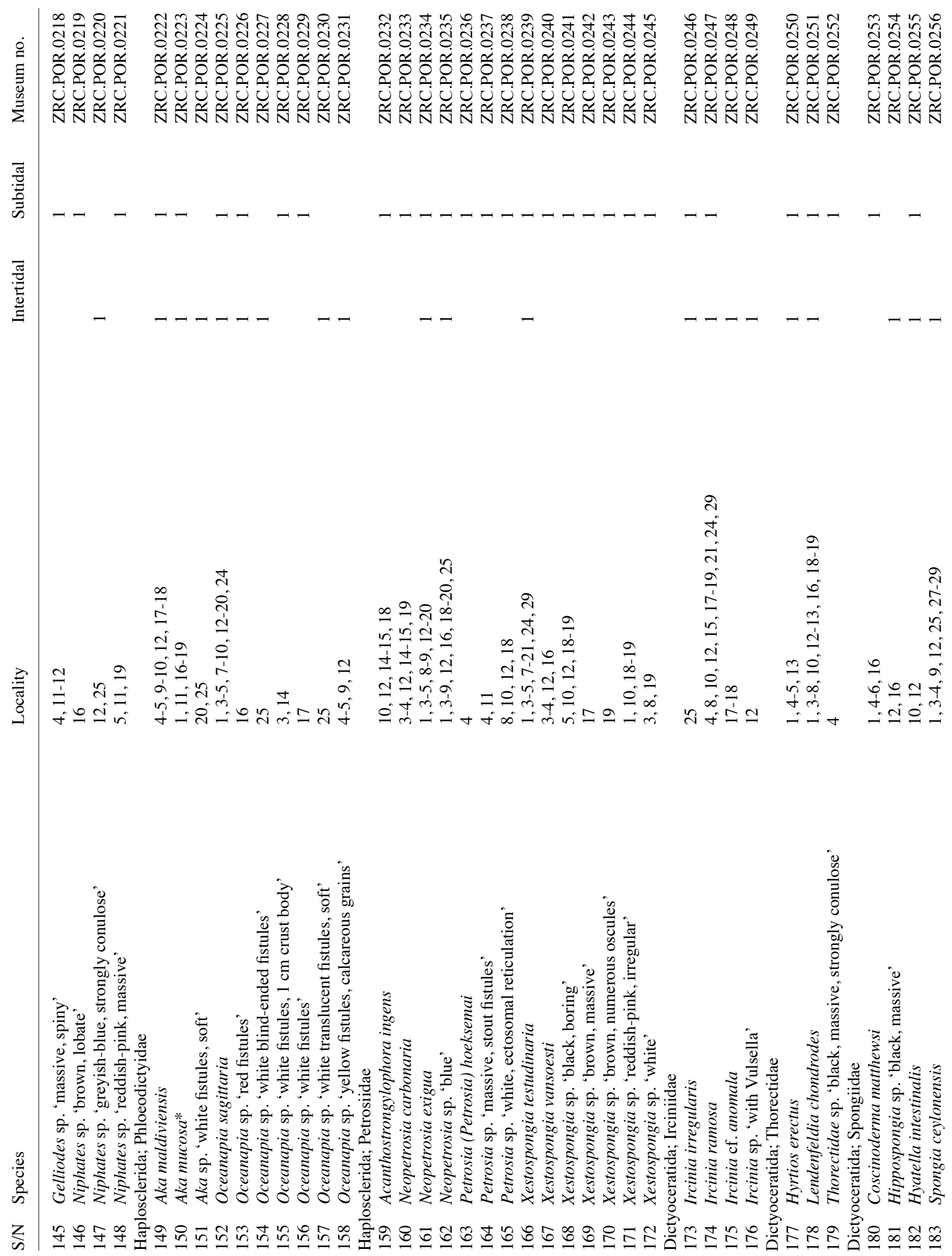


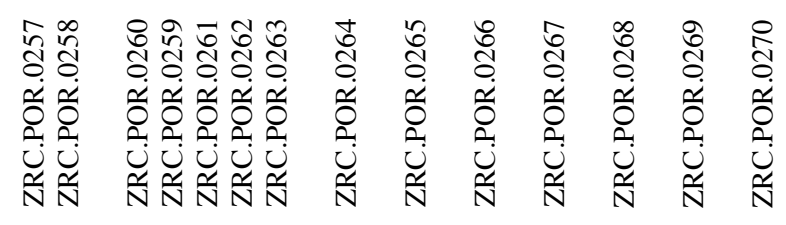

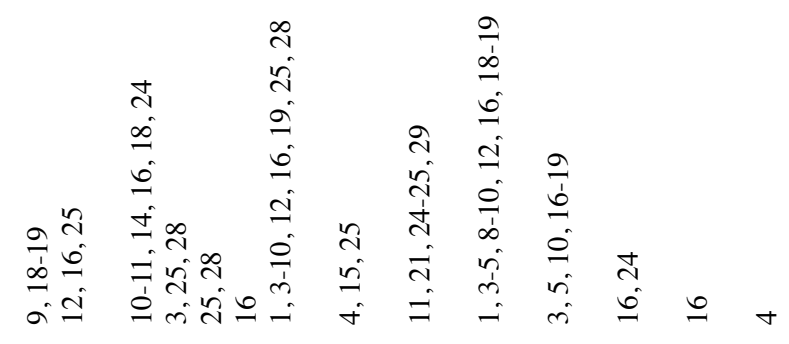

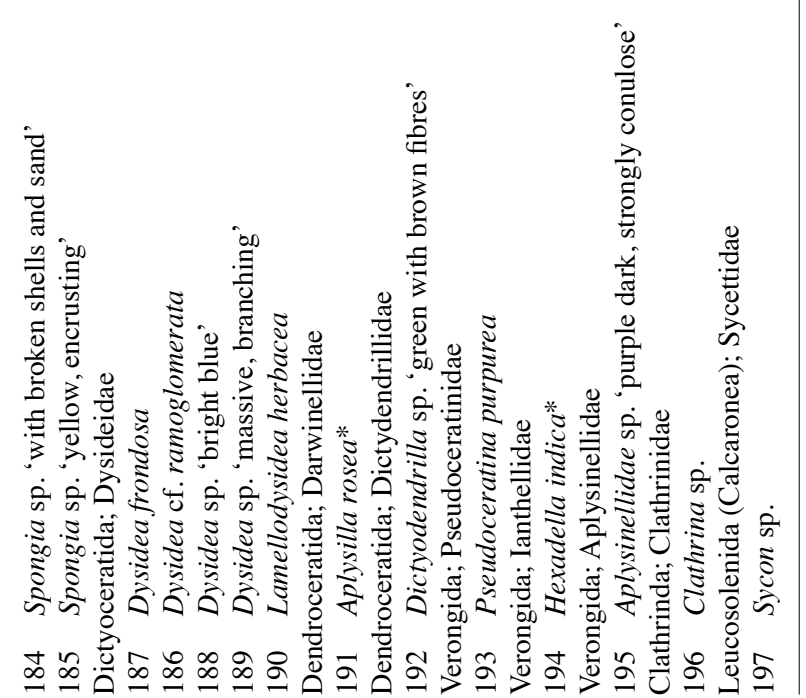




\begin{tabular}{|c|c|c|c|}
\hline Station & Latitude & Longitude & Sampling date \\
\hline E. Johor Strait & $1^{\circ} 26.233^{\prime} \mathrm{N}$ & $104^{\circ} 2.860^{\prime} \mathrm{E}$ & 21.v.2003 \\
\hline E. Johor Strait & $1^{\circ} 26.233^{\prime} \mathrm{N}$ & $104^{\circ} 2.860^{\prime} \mathrm{E}$ & 13.viii. 2003 \\
\hline E. Johor Strait & $1^{\circ} 26.233^{\prime} \mathrm{N}$ & $104^{\circ} 2.860^{\prime} \mathrm{E}$ & 16.x.2003 \\
\hline St John & $1^{\circ} 13.362^{\prime} \mathrm{N}$ & $103^{\circ} 50.667^{\prime} \mathrm{E}$ & 27.xi.2003 \\
\hline E. Johor Strait & $1^{\circ} 26.233^{\prime} \mathrm{N}$ & $104^{\circ} 2.860^{\prime} \mathrm{E}$ & 10.iv.2004 \\
\hline E. Johor Strait & $1^{\circ} 26.233^{\prime} \mathrm{N}$ & $104^{\circ} 2.860^{\prime} \mathrm{E}$ & 5.viii.2004 \\
\hline E. Johor Strait & $1^{\circ} 26.233^{\prime} \mathrm{N}$ & $104^{\circ} 2.860^{\prime} \mathrm{E}$ & 10.ix.2004 \\
\hline St John & $1^{\circ} 13.362^{\prime} \mathrm{N}$ & $103^{\circ} 50.667^{\prime} \mathrm{E}$ & 4.ii.2005 \\
\hline E. Johor Strait & $1^{\circ} 26.233^{\prime} \mathrm{N}$ & $104^{\circ} 2.860^{\prime} \mathrm{E}$ & 25.viii.2005 \\
\hline E. Johor Strait & $1^{\circ} 26.233^{\prime} \mathrm{N}$ & $104^{\circ} 2.860^{\prime} \mathrm{E}$ & 4.xii. 2005 \\
\hline P. Semakau & $1^{\circ} 12.350^{\prime} \mathrm{N}$ & $103^{\circ} 45.343^{\prime} \mathrm{E}$ & 27.iii.2006 \\
\hline E. Johor Strait & $1^{\circ} 26.233^{\prime} \mathrm{N}$ & $104^{\circ} 2.860^{\prime} \mathrm{E}$ & 28.iii.2006 \\
\hline P. Hantu & $1^{\circ} 13.544^{\prime} \mathrm{N}$ & $103^{\circ} 44.987^{\prime} \mathrm{E}$ & 10.iv.2006 \\
\hline P. Tekukor & $1^{\circ} 13.924^{\prime} \mathrm{N}$ & $103^{\circ} 50.277^{\prime} \mathrm{E}$ & 11.iv.2006 \\
\hline E. Johor Strait & $1^{\circ} 26.233^{\prime} \mathrm{N}$ & $104^{\circ} 2.860^{\prime} \mathrm{E}$ & 2.v.2006 \\
\hline E. Johor Strait & $1^{\circ} 26.233^{\prime} \mathrm{N}$ & $104^{\circ} 2.860^{\prime} \mathrm{E}$ & 29.v.2006 \\
\hline Lazarus island & $1^{\circ} 13.695^{\prime} \mathrm{N}$ & $103^{\circ} 51.229^{\prime} \mathrm{E}$ & 13.vi.2006 \\
\hline E. Johor Strait & $1^{\circ} 26.233^{\prime} \mathrm{N}$ & $104^{\circ} 2.860^{\prime} \mathrm{E}$ & 29.vi.2006 \\
\hline E. Johor Strait & $1^{\circ} 26.233^{\prime} \mathrm{N}$ & $104^{\circ} 2.860^{\prime} \mathrm{E}$ & 12.vii.2006 \\
\hline E. Johor Strait & $1^{\circ} 26.233^{\prime} \mathrm{N}$ & $104^{\circ} 2.860^{\prime} \mathrm{E}$ & 10.viii.2006 \\
\hline E. Johor Strait & $1^{\circ} 26.233^{\prime} \mathrm{N}$ & $104^{\circ} 2.860^{\prime} \mathrm{E}$ & 10.ix.2006 \\
\hline E. Johor Strait & $1^{\circ} 26.233^{\prime} \mathrm{N}$ & $104^{\circ} 2.860^{\prime} \mathrm{E}$ & 11.x.2006 \\
\hline E. Johor Strait & $1^{\circ} 26.233^{\prime} \mathrm{N}$ & $104^{\circ} 2.860^{\prime} \mathrm{E}$ & 8.xi.2006 \\
\hline St John & $1^{\circ} 13.362^{\prime} \mathrm{N}$ & $103^{\circ} 50.667^{\prime} \mathrm{E}$ & 25.xi.2006 \\
\hline E. Johor Strait & $1^{\circ} 26.233^{\prime} \mathrm{N}$ & $104^{\circ} 2.860^{\prime} \mathrm{E}$ & 7.xii.2006 \\
\hline Changi & $1^{\circ} 23.606^{\prime} \mathrm{N}$ & $103^{\circ} 59.063^{\prime} \mathrm{E}$ & 18.i.2007 \\
\hline E. Johor Strait & $1^{\circ} 26.233^{\prime} \mathrm{N}$ & $104^{\circ} 2.860^{\prime} \mathrm{E}$ & 22.i.2007 \\
\hline P. Semakau & $1^{\circ} 12.350^{\prime} \mathrm{N}$ & $103^{\circ} 45.343^{\prime} \mathrm{E}$ & 3.ii.2007 \\
\hline E. Johor Strait & $1^{\circ} 26.233^{\prime} \mathrm{N}$ & $104^{\circ} 2.860^{\prime} \mathrm{E}$ & 20.ii.2007 \\
\hline Kranji & $1^{\circ} 27.013^{\prime} \mathrm{N}$ & $103^{\circ} 43.446^{\prime} \mathrm{E}$ & 21.ii.2007 \\
\hline Kranji & $1^{\circ} 26.360^{\prime} \mathrm{N}$ & $103^{\circ} 45.804^{\prime} \mathrm{E}$ & 22.ii. 2007 \\
\hline P. Pawai & $1^{\circ} 10.816^{\prime} \mathrm{N}$ & $103^{\circ} 43.155^{\prime} \mathrm{E}$ & 18.iii.2007 \\
\hline E. Johor Strait & $1^{\circ} 26.233^{\prime} \mathrm{N}$ & $104^{\circ} 2.860^{\prime} \mathrm{E}$ & 23.iii.2007 \\
\hline St John & $1^{\circ} 13.362^{\prime} \mathrm{N}$ & $103^{\circ} 50.667^{\prime} \mathrm{E}$ & 7.iv.2007 \\
\hline P. Biola & $1^{\circ} 9.853^{\prime} \mathrm{N}$ & $103^{\circ} 44.523^{\prime} \mathrm{E}$ & 20.iv.2007 \\
\hline T. Rimau & $1^{\circ} 15.519^{\prime} \mathrm{N}$ & $103^{\circ} 48.601^{\prime} \mathrm{E}$ & 21.iv.2007 \\
\hline Kusu island & $1^{\circ} 13.366^{\prime} \mathrm{N}$ & $103^{\circ} 51.674^{\prime} \mathrm{E}$ & 5.v.2007 \\
\hline P. Tekukor & $1^{\circ} 13.924^{\prime} \mathrm{N}$ & $103^{\circ} 50.277^{\prime} \mathrm{E}$ & 18.v.2007 \\
\hline Sisters' island & $1^{\circ} 12.869^{\prime} \mathrm{N}$ & $103^{\circ} 50.025^{\prime} \mathrm{E}$ & 19.v.2007 \\
\hline P. Sekudu & $1^{\circ} 24.259^{\prime} \mathrm{N}$ & $103^{\circ} 59.324^{\prime} \mathrm{E}$ & 22.v.2007 \\
\hline St John & $1^{\circ} 13.362^{\prime} \mathrm{N}$ & $103^{\circ} 50.667^{\prime} \mathrm{E}$ & 29.v.2007 \\
\hline Changi & $1^{\circ} 23.606^{\prime} \mathrm{N}$ & $103^{\circ} 59.063^{\prime} \mathrm{E}$ & 4.vi.2007 \\
\hline St John & $1^{\circ} 13.362^{\prime} \mathrm{N}$ & $103^{\circ} 50.667^{\prime} \mathrm{E}$ & 6.vi.2007 \\
\hline Labrador & $1^{\circ} 15.9900^{\prime} \mathrm{N}$ & $103^{\circ} 48.022^{\prime} \mathrm{E}$ & 15.vi.2007 \\
\hline Cyrene & $1^{\circ} 15.674^{\prime} \mathrm{N}$ & $103^{\circ} 45.028^{\prime} \mathrm{E}$ & 16.vi.2007 \\
\hline East Coast & $1^{\circ} 17.565^{\prime} \mathrm{N}$ & $103^{\circ} 54.278^{\prime} \mathrm{E}$ & 17.vi.2007 \\
\hline Raffles lighthouse & $1^{\circ} 9.558^{\prime} \mathrm{N}$ & $103^{\circ} 44.459^{\prime} \mathrm{E}$ & 18.vi.2007 \\
\hline P. Jong & $1^{\circ} 12.917^{\prime} \mathrm{N}$ & $103^{\circ} 47.179^{\prime} \mathrm{E}$ & 4.vii. 2007 \\
\hline Pasir Ris & $1^{\circ} 22.934^{\prime} \mathrm{N}$ & $103^{\circ} 57.407^{\prime} \mathrm{E}$ & 5.vii. 2007 \\
\hline E. Johor Strait & $1^{\circ} 26.233^{\prime} \mathrm{N}$ & $104^{\circ} 2.860^{\prime} \mathrm{E}$ & 18.vii.2007 \\
\hline Merawang & $1^{\circ} 19.518^{\prime} \mathrm{N}$ & $103^{\circ} 37.633^{\prime} \mathrm{E}$ & 2.viii. 2007 \\
\hline Chek Jawa & $1^{\circ} 24.531^{\prime} \mathrm{N}$ & $103^{\circ} 59.576^{\prime} \mathrm{E}$ & 3.viii.2007 \\
\hline E. Johor Strait & $1^{\circ} 26.233^{\prime} \mathrm{N}$ & $104^{\circ} 2.860^{\prime} \mathrm{E}$ & 20.viii. 2007 \\
\hline E. Johor Strait & $1^{\circ} 26.233^{\prime} \mathrm{N}$ & $104^{\circ} 2.860^{\prime} \mathrm{E}$ & 28.x.2007 \\
\hline E. Johor Strait & $1^{\circ} 26.233^{\prime} \mathrm{N}$ & $104^{\circ} 2.860^{\prime} \mathrm{E}$ & 27.xi.2007 \\
\hline
\end{tabular}



P. Hantu
$1^{\circ} 13.544^{\prime} \mathrm{N} \quad 103^{\circ} 44.987^{\prime} \mathrm{E}$
23.vii.2007
E. Johor Strait
$1^{\circ} 26.233^{\prime} \mathrm{N} \quad 104^{\circ} 2.860^{\prime} \mathrm{E}$
25.xii. 2007
P. Semakau
$1^{\circ} 12.350^{\prime} \mathrm{N} \quad 103^{\circ} 45.343^{\prime} \mathrm{E}$
20.ii.2007 
Latitude Longitude Sampling date

Kusu Island, northwestern reef

$1^{\circ} 13.5055^{\prime} \mathrm{N} \quad 103^{\circ} 51.434^{\prime} \mathrm{E} \quad 22 . v .2009$

P. Tekukor, eastern reef

P. Tekukor, eastern reef

P. Tekukor, eastern reef

P. Semakau, southwestern reef

P. Semakau, southwestern reef

P. Hantu, southwestern reef

Terumbu Hantu

P. Jong, southwestern reef

P. Jong, southwestern reef

P. Semakau, southwestern reef

P. Semakau, southwestern reef

P. Subar Laut, southwestern reef (The Sisters' Islands)

P. Subar Darat, southwestern reef (The Sisters' Islands)

P. Hantu, southwestern reef

Terumbu Hantu

P. Pawai, northern reef

P. Pawai, northern reef

P. Senang, western reef

P. Senang, northwestern reef

St. John's island, northwestern reef

Kusu Island, eastern reef

St. John's Island, southwestern reef

P. Tekukor, eastern reef

P. Satumu (Raffles Lighthouse), western reef

P. Satumu (Raffles Lighthouse), western reef

P. Satumu (Raffles Lighthouse), western reef

P. Hantu, western reef

P. Biola, western reef

P. Biola, western reef

P. Sudong, northeastern reef

P. Sudong, northern reef

Kusu Island, southeastern reef

St. John's Island, southwestern reef

P. Pawai, southwestern reef

P. Pawai, southwestern reef

P. Salu, southern reef

P. Salu, northern reef

P. Pawai, northwestern reef

P. Pawai, northwestern reef

Sinki Fairway (Dredging)

P. Biola, western reef

P. Biola, western reef

P. Berkas, southern reef

P. Pawai, southwestern reef

Labrador

Cyrene, western reef

P. Satumu (Raffles Lighthouse), western reef

P. Satumu (Raffles Lighthouse), eastern reef

P. Tekukor, southern reef

P. Hantu, southern reef

St. John's Island, southwestern reef

St. John's Island, southwestern reef

West Johor Strait, off Merawang Beacon (dredging)

West Johor Strait, off Merawang Beacon (dredging)

West Johor Strait, off Merawang Beacon (dredging)

West Johor Strait, off Merawang Beacon (dredging)

West Johor Strait, off Merawang Beacon (dredging)

Selat Sinki

East Johor Strait, off P. Ubin (dredging)

East Johor Strait, off P. Ubin (dredging)

East Johor Strait, off P. Ubin (dredging)

East Johor Strait, off P. Ubin (dredging)

East Johor Strait, off P. Ubin (dredging)

$1^{\circ} 13.907^{\prime} \mathrm{N} \quad 103^{\circ} 50.378^{\prime} \mathrm{E}$

$1^{\circ} 13.907{ }^{\prime} \mathrm{N} \quad 103^{\circ} 50.378^{\prime} \mathrm{E}$

$1^{\circ} 13.907 ' \mathrm{~N} \quad 103^{\circ} 50.378^{\prime} \mathrm{E}$

$1^{\circ} 11.7799^{\prime} \mathrm{N} \quad 103^{\circ} 45.448^{\prime} \mathrm{E}$

$1^{\circ} 11.779^{\prime} \mathrm{N} \quad 103^{\circ} 45.448^{\prime} \mathrm{E}$

$1^{\circ} 13.3422^{\prime} \mathrm{N} \quad 103^{\circ} 44.928^{\prime} \mathrm{E}$

$1^{\circ} 13.574^{\prime} \mathrm{N} \quad 103^{\circ} 44.739^{\prime} \mathrm{E}$

$1^{\circ} 12.859^{\prime} \mathrm{N} \quad 103^{\circ} 47.241^{\prime} \mathrm{E}$

$1^{\circ} 12.859^{\prime} \mathrm{N} \quad 103^{\circ} 47.241^{\prime} \mathrm{E}$

$1^{\circ} 11.7799^{\prime} \mathrm{N} \quad 103^{\circ} 45.448^{\prime} \mathrm{E}$

$1^{\circ} 11.779$ ' $\quad 103^{\circ} 45.448^{\prime} \mathrm{E}$

$1^{\circ} 12.751^{\prime} \mathrm{N} \quad 103^{\circ} 50.020^{\prime} \mathrm{E}$

$1^{\circ} 12.898^{\prime} \mathrm{N} \quad 103^{\circ} 49.904^{\prime} \mathrm{E}$

$1^{\circ} 13.342^{\prime} \mathrm{N} \quad 103^{\circ} 44.928^{\prime} \mathrm{E}$

$1^{\circ} 13.5744^{\prime} \mathrm{N} \quad 103^{\circ} 44.739^{\prime} \mathrm{E}$

$1^{\circ} 11.530^{\prime} \mathrm{N} \quad 103^{\circ} 43.107^{\prime} \mathrm{E}$

$1^{\circ} 11.530^{\prime} \mathrm{N} \quad 103^{\circ} 43.107^{\prime} \mathrm{E}$

$1^{\circ} 10.285^{\prime} \mathrm{N} \quad 103^{\circ} 43.584^{\prime} \mathrm{E}$

$1^{\circ} 10.548^{\prime} \mathrm{N} \quad 103^{\circ} 43.568^{\prime} \mathrm{E}$

$1^{\circ} 13.286^{\prime} \mathrm{N} \quad 103^{\circ} 50.584^{\prime} \mathrm{E}$

$1^{\circ} 13.469^{\prime} \mathrm{N} \quad 103^{\circ} 51.723^{\prime} \mathrm{E}$

$1^{\circ} 12.928^{\prime} \mathrm{N} \quad 103^{\circ} 50.902^{\prime} \mathrm{E}$

$1^{\circ} 13.907{ }^{\prime} \mathrm{N} \quad 103^{\circ} 50.378^{\prime} \mathrm{E}$

$1^{\circ} 9.537^{\prime} \mathrm{N} \quad 103^{\circ} 44.323^{\prime} \mathrm{E}$

$1^{\circ} 9.537^{\prime} \mathrm{N} \quad 103^{\circ} 44.323^{\prime} \mathrm{E}$

$1^{\circ} 9.537^{\prime} \mathrm{N} \quad 103^{\circ} 44.323^{\prime} \mathrm{E}$

$1^{\circ} 13.387^{\prime} \mathrm{N} \quad 103^{\circ} 44.856^{\prime} \mathrm{E}$

$1^{\circ} 9.856^{\prime} \mathrm{N} \quad 103^{\circ} 44.449^{\prime} \mathrm{E}$

$1^{\circ} 9.856^{\prime} \mathrm{N} \quad 103^{\circ} 44.4499^{\prime} \mathrm{E}$

$1^{\circ} 12.642 ' \mathrm{~N} \quad 103^{\circ} 43.830^{\prime} \mathrm{E}$

$1^{\circ} 12.809$ ' $\mathrm{N} \quad 103^{\circ} 43.001$ 'E

$1^{\circ} 13.045^{\prime} \mathrm{N} \quad 103^{\circ} 51.328^{\prime} \mathrm{E}$

$1^{\circ} 12.928^{\prime} \mathrm{N} \quad 103^{\circ} 50.902^{\prime} \mathrm{E}$

$1^{\circ} 10.799 ' \mathrm{~N} \quad 103^{\circ} 42.940^{\prime} \mathrm{E}$

$1^{\circ} 10.799^{\prime} \mathrm{N} \quad 103^{\circ} 42.940^{\prime} \mathrm{E}$

$1^{\circ} 12.924^{\prime} \mathrm{N} \quad 103^{\circ} 42.306^{\prime} \mathrm{E}$

$1^{\circ} 13.173^{\prime} \mathrm{N} \quad 103^{\circ} 42.502^{\prime} \mathrm{E}$

$1^{\circ} 11.117^{\prime} \mathrm{N} \quad 103^{\circ} 42.902^{\prime} \mathrm{E}$

$1^{\circ} 11.117^{\prime} \mathrm{N} \quad 103^{\circ} 42.902^{\prime} \mathrm{E}$

$1^{\circ} 14.238^{\prime} \mathrm{N} \quad 103^{\circ} 43.804^{\prime} \mathrm{E}$

$1^{\circ} 9.856^{\prime} \mathrm{N} \quad 103^{\circ} 44.449^{\prime} \mathrm{E}$

$1^{\circ} 9.856^{\prime} \mathrm{N} \quad 103^{\circ} 44.449^{\prime} \mathrm{E}$

$1^{\circ} 11.404^{\prime} \mathrm{N} \quad 103^{\circ} 44.478^{\prime} \mathrm{E}$

$1^{\circ} 10.799^{\prime} \mathrm{N} \quad 103^{\circ} 42.940^{\prime} \mathrm{E}$

$1^{\circ} 15.926^{\prime} \mathrm{N} \quad 103^{\circ} 48.005^{\prime} \mathrm{E}$

$1^{\circ} 15.764{ }^{\prime} \mathrm{N} \quad 103^{\circ} 44.850^{\prime} \mathrm{E}$

$1^{\circ} 9.537^{\prime} \mathrm{N} \quad 103^{\circ} 44.323^{\prime} \mathrm{E}$

$1^{\circ} 9.596^{\prime} \mathrm{N} \quad 103^{\circ} 44.509^{\prime} \mathrm{E}$

$1^{\circ} 13.780^{\prime} \mathrm{N} \quad 103^{\circ} 50.245^{\prime} \mathrm{E}$

$1^{\circ} 13.387^{\prime} \mathrm{N} \quad 103^{\circ} 44.856^{\prime} \mathrm{E}$

$1^{\circ} 12.928^{\prime} \mathrm{N} \quad 103^{\circ} 50.902^{\prime} \mathrm{E}$

$1^{\circ} 12.928^{\prime} \mathrm{N} \quad 103^{\circ} 50.902^{\prime} \mathrm{E}$

$1^{\circ} 17.070$ ' $\quad 103^{\circ} 36.415^{\prime} \mathrm{E}$

$1^{\circ} 18.673^{\prime} \mathrm{N} \quad 103^{\circ} 37.190^{\prime} \mathrm{E}$

$1^{\circ} 19.733^{\prime} \mathrm{N} \quad 103^{\circ} 37.641^{\prime} \mathrm{E}$

$1^{\circ} 22.563{ }^{\prime} \mathrm{N} \quad 103^{\circ} 38.864^{\prime} \mathrm{E}$

$1^{\circ} 21.828^{\prime} \mathrm{N} \quad 103^{\circ} 38.431^{\prime} \mathrm{E}$

$1^{\circ} 13.715^{\prime} \mathrm{N} \quad 103^{\circ} 43.438^{\prime} \mathrm{E}$

$1^{\circ} 24.069^{\prime} \mathrm{N} \quad 104^{\circ} 00.128^{\prime} \mathrm{E}$

$1^{\circ} 24.098^{\prime} \mathrm{N} \quad 103^{\circ} 58.579^{\prime} \mathrm{E}$

$1^{\circ} 23.668^{\prime} \mathrm{N} \quad 103^{\circ} 57.512^{\prime} \mathrm{E}$

$1^{\circ} 25.252^{\prime} \mathrm{N} \quad 103^{\circ} 55.288^{\prime} \mathrm{E}$

$1^{\circ} 25.648$ ' $\mathrm{N} \quad 103^{\circ} 56.255^{\prime} \mathrm{E}$ 22.v. 2009

16.vi.2009

16.vi.2009

24.vi.2009

24.vi.2009

28.vi.2009

28.vi.2009

13.vii.2009

13.vii.2009

5.viii.2009

5.viii.2009

24.viii.2009

24.viii.2009

30.viii.2009

30.viii.2009

6.ix.2009

6.ix.2009

7.ix.2009

7.ix.2009

19.ix.2009

19.ix.2009

1.x.2009

1.x.2009

2.x.2009

2.x.2009

10.xi.2009

10.xi.2009

12.xi.2009

12.xi.2009

27.xi.2009

27.xi.2009

8.i. 2010

8.i. 2010

23.i.2010

23.i. 2010

24.i.2010

24.i. 2010

21.ii. 2010

21.ii. 2010

22.ii. 2010

5.iii. 2010

5.iii. 2010

6.iii. 2010

6.iii.2010

18.iii. 2010

18.iii. 2010

29.iii. 2010

29.iii.2010

30.iii.2010

1.iv.2010

14.iv. 2010

14.iv. 2010

26.iv. 2010

26.iv. 2010

26.iv. 2010

26.iv. 2010

26.iv. 2010

26.iv. 2010

28.iv. 2010

28.iv. 2010

28.iv. 2010

28.iv. 2010

28.iv. 2010 
East Johor Strait, off Northern P. Tekong (dredging) East Johor Strait, off Northern P. Tekong (dredging) East Johor Strait, off Northern P. Tekong (dredging) East Johor Strait, off Northern P. Tekong (dredging) $1^{\circ} 24.679 ' \mathrm{~N} \quad 104^{\circ} 05.231$ 'E

$1^{\circ} 25.162{ }^{\prime} \mathrm{N} \quad 104^{\circ} 04.918^{\prime} \mathrm{E}$

$1^{\circ} 25.889^{\prime} \mathrm{N} \quad 104^{\circ} 04.118^{\prime} \mathrm{E}$

$1^{\circ} 26.013{ }^{\prime} \mathrm{N} \quad 104^{\circ} 03.657^{\prime} \mathrm{E}$ 7.vi. 2010

7.vi. 2010

7.vi.2010

7.vi.2010 